\title{
Obesitateak minbizia izateko arriskua handitzen du... Zer mekanismo daude tartean?
}

(Obesity increases the risk of cancer... which mechanisms are involved?)

\author{
Saioa Gómez-Zorita, Jenifer Trepiana*, Itziar Eseberri, María Puy Portillo \\ Farmazia eta Elikagaien Zientziak Saila. Farmazia Fakultatea \\ (UPV/EHU, Vitoria-Gasteiz) \\ Bioaraba Osasunaren Ikerketa Zentroa, Vitoria-Gasteiz eta CIBERobn, \\ (Instituto de Salud Carlos III. Madrid)
}

\begin{abstract}
LABURPENA: Minbizia egungo osasun-arazo publiko garrantzitsuenetarikoa da; izan ere, tumoreen intzidentzia izugarri handitu da azken hamarkadetan. Beste faktore askoren artean, elikadura-patroiak nabarmen eragiten du minbiziaren garapenean; hala nola, obesitateak eta haren komorbilitateek. Hainbat minbizi mota garatzeko arriskua areagotzen dute, besteak beste gizon eta emakumezkoetan tiroide, hestegorri, gibel, behazun-besikula, kolon, giltzurrun eta mieloma anitzeko minbiziak, bular eta endometrioko minbiziak emakumezkoen kasuan eta prostatakoa gizonezkoenean. Azken urteetan nahiko ikertu da obesitatea-minbizia harremanean, baina oraindik ez dira ondorio garbiak lortu erlazio hori ezartzen duten mekanismo-multzoei dagokienez. Minbiziaren eta obesitatearen arteko asoziazioari laguntzen dioten mekanismoak aldaketa hormonalekin erlazionaturikoak izaten dira, besteak beste intsulina, intsulinaren antzekoa den 1 hazkuntza hormona (IGF-1) edo sexu-esteroideak. Hormonak ez ezik, adipokinek (leptina eta adiponektina) eta hanturak ere parte hartzen dute minbiziaren garapenean. Era berean, obesitatea eta minbizia pairatzen duten pazienteek metastasi-arrisku handiagoa dute, eta ondorioz, biziraupen-ratio baxuagoa. Ikerketa pre-klinikoetan ikusi ahal izan denez, obesitateak metastasia bultzatzen du melanoma eta birika-minbizi ereduetan. Obesitateak paziente onkologikoen hilkortasun-tasa altuarekin duen lotura ikusita, ezinbestekotzat jotzen da minbizia duten pazienteetan, elikadura-patroi osasuntsuarekin eta jarduera fisikoarekin batera, obesitatea eta sindrome metabolikoa tratatzeko farmakoen erabilera; besteak beste, metformina, tiazolidinedionak eta estatinak erabili ohi dira. Amaitzeko, aipatzekoa da ikerlan gehiagoren beharra dagoela parte hartzen duten mekanismoak ondo ulertu ahal izateko, eta are gehiago, etorkizunean minbiziaren diagnostiko goiztiarrerako baliagarriak izan litezkeen bio-markatzaileak aurkitzeko.
\end{abstract}

HITZ GAKOAK: Obesitatea, minbizia, hantura, adipokinak, hormonak, intsulina.

\begin{abstract}
Cancer is one of the most important public health problems of the last years, due to the fact that tumour incidence has increased dramatically over the last decade. Among other factors, the dietary pattern notably influences the development of cancer, as well as obesity and its comorbidities do. They increase the risk of developing several types of cancer: thyroid, esophagus, liver, gallbladder, colon, kidney and multiple myeloma cancer in men and women, breast and endometrium cancer in women and prostate cancer in men. However, the mechanism by which obesity can induce cancer has not been widely investigated. The known mechanisms that contribute to the association between cancer and obesity are related to hormonal changes, such as insulin and insulin-like growth hormone-1 (IGF-1), or sex steroids. Not only hormones can affect cancer development, but also adipokines (leptin and adiponectin) and inflammation. In the same way, patients with obesity and cancer have a higher risk of suffering metastasis, consequently having a lower survival rate. As pre-clinical research has shown, obesity can induce metastasis in melanoma and lung cancer models. Since it has been reported a relationship between obesity and a high mortality rate in oncological patients, it is essential to use drugs to treat obesity and metabolic syndrome in cancer patients, such as metformin, thiazolidinediones and statins. Finally, it is noteworthy to mention that further research is needed to better understand the mechanisms involved in this process, and even to find biomarkers that may be useful for an early cancer diagnosis.
\end{abstract}

KEYWORDS: Obesity, cancer, inflammation, adipokines, hormones, insulin.

* Harremanetan jartzeko / Corresponding author: Jenifer Trepiana. Farmazia eta Elikagaien Zientziak Saila. Farmazia Fakultatea, UPV/EHU. Unibertsitate Pasealekua, 7 (01006 Vitoria-Gasteiz). - jenifer.trepiana@ehu.eus - https://orcid.org/00000003-1316-5923.

Nola aipatu / How to cite: Gómez-Zorita, Saioa; Trepiana, Jenifer; Eseberri, Itziar; Puy Portillo, María (2020). "Obesitateak minbizia izateko arriskua handitzen du... Zer mekanismo daude tartean?»; Ekaia, 38, 2020, 11-25. (https://doi.org/10.1387/ekaia.21604).

Jasoa: 25 martxoa, 2020; Onartua: 23 ekaina, 2020.

ISSN 0214-9001 - elSSN 2444-3255 / (C) 2020 UPV/EHU

(c) (i) (0) Obra hau Creative Commons Atribución 4.0 Internacional-en

lizentziapean dago 
Saioa Gómez-Zorita, Jenifer Trepiana, Itziar Eseberri, María Puy Portillo

\section{SARRERA}

Minbizia zelulen kontrolik gabeko hazkuntza inbasiboak ezaugarrituriko gaixotasunen multzoa da [1]. Gaixotasunaren hasiera zelula batean gertatutako mutazio batek edo gehiagok determinatuko du; izan ere, zelulen neurrigabeko hazkuntza eta zatiketa, zelulen diferentziazio-prozesuaren inhibizioa eta heriotza zelularraren saihestea gertatzen da [2].

Minbizia gaur egungo osasun-arazo publiko garrantzitsuenetarikoa da, mundu-mailako hilkortasunaren kausa nagusietarikoa. Minbiziaren Ikerketarako Nazioarteko Erakundearen (IARC, GLOBOCAN18 proiektua) arabera, 2012. urtean tumoreen intzidentzia 14 milioikoa zen, eta 2018. urtean 18.1 milioikoa izatera pasatu zen [3]. Minbizi-kasuen \% 5-10 faktore genetikoek eragiten dituzte; gainerako \% 90-95, berriz, bizi-estiloak eta ingurumeneko faktoreek. Datu estatistikoek agerian utzi dutenez, minbizien $\%$ 30-35 elikadura-patroiak eragiten ditu, \% 15-20 infekzioek, eta gainerako kasuen etiopatogenian, eragile garrantzitsuenak erradiazioa, estresa, poluzioa edo alkoholaren kontsumoa daude [4].

Denbora luzez elikagaien bidez hartzen dugun energia gastatzen duguna baino gehiago denean, gure gorputzean gehiegizko gantza metatuko dugu, eta horrek obesitatearen garapenari hasiera emango dio. Gizakiontzat gantza pilatzeko dugun ahalmena urteetan zehar elikagaien eskasia izaten zenerako abantaila garrantzitsua izan bada ere, gaur egun ez da ohiko egoera Mendebaldeko populazioetan; horrek gure kontra jo du, eta obesitatea osasun-arazo larriak eragiten dituen XXI. mendeko pandemia bilakatu da [5]. Obesitatea faktore anitzeko gaixotasuna da, zeinari faktore genetikoek eta bizitza-estiloak eragiten dioten batik bat, nahiz ezin dugun baztertu gizarte-faktoreek eta asaldura metabolikoek duten rola [6]. Jakina da gainpisuak eta obesitateak 2 motako diabetesa eta gaixotasun kardiobaskularren arriskua nabarmenki handitzen duten asaldura metabolikoen multzoa eragiten duela, gaur egun sindrome metabolikoa izenez ezagutzen dena. Halaber, obesitateak minbiziaren garapenaren gain duen eragina oso ikertua izan da, zeren eta gorputz-pisu handiegia duten pertsonek zenbait minbizi mota garatzeko arrisku handiagoa dutela baieztatu baita: gizon eta emakumezkoetan, tiroide, hestegorri, gibel, behazun-besikula, kolon, giltzurrun eta mieloma anitzeko minbiziak; emakumezkoen kasuan bular eta endometrioko minbiziak, eta gizonezkoenean prostatakoa [7, 8]. Aipatzekoa da emakumeetan gertatzen den obesitatearen eta minbiziaren arteko erlazioa menopausiaren araberakoa dela, endometrioko minbiziaren eta estrogenoen hartzailerako positiboak $(\mathrm{ER}+)$ diren bularreko minbiziaren kasuan bereziki. Horren arrazoia da menopausiaren ondoren gantz-ehuna estrogenoen ekoizle garrantzitsuena dela $[9,10]$.

Bi gaixotasunen arteko asoziazioari laguntzen dioten mekanismoak asko izan daitezke, baina oro har hanturarekin eta organismoko aldaketa 
hormonalekin erlazionaturikoak izaten dira. Duela 25 urtetik gaurdaino jasotako datuek aditzera eman dutenez, minbiziaren ondoriozko heriotzen artean, obesitatea eragile zuzen eta kausala izan zen gizonezkoen \% 14an eta emakumezkoen \% 20an [11]. Hori dela eta, ezinbestekoa da obesitatearen eta minbiziaren arteko loturan parte hartzen duten mekanismoak ondo zehaztea. Bestalde, obesitatearen, minbizi-arriskuaren eta hilkortasunaren arteko erlazioa 2002. urtean ezarri zen, Bianchinik eta haren kolaboratzaileek eginiko ikerlan bati esker [12]. Gaur egun, obesitateari egozten zaion minbizia pairatzeko arriskua \% 11.9 da gizonezkoetan, eta $\% 13.1$ emakumezkoetan [8]. Calle-k eta haren kolaboratzaileek eginiko beste ikerlan batean, ondorioztatu zen, gorputz-pisu osasuntsua zuten pertsonekin alderatuta, gorputz-masaren indizea (GMI) 40 baino altuagoa zuten gizonezkoen hilkortasun-tasa $\% 52$ handiagoa zela, eta emakumezkoen kasuan \% 62 handiagoa [13]. Izan ere, estimatu denez, GMI 5kg/ $\mathrm{m}^{2}$ handitzen denean minbiziak eragindako hilkortasuna $\% 10$ handitzen da [14]. Halaber, 2014. urtean Ameriketako Estatu Batuetan diagnostikaturiko minbizi-kasuen \% 40 gainpisuarekin eta obesitatearekin erlazionatuta zeuden [7].

Obesitateak minbizia izateko arriskua izugarri handitu dezakeela jakina bada ere, ikerlan gehienak epidemiologikoak dira, behaketa-ikerketa prospektiboak hain zuzen, non kausa-ondorio harremanak zehazten diren baina fenomeno horren erantzule diren mekanismo biologikoak ez diren gehiegi deskribatzen. Obesitateak gantz-ehunak bere erregulazio-ahalmena galaraztea eragiten duela uste da, azken batean minbizia eraginez, baina ezinbestekoa da mekanismo horietan gehiago sakontzea. Nolanahi ere, gaurdaino eskuratu diren datuak aintzat hartuta, artikulu honen helburua da aipaturiko mekanismo horiek laburbildu eta azaltzea (1. irudia).

\section{MINBIZIA ETA OBESITATEA ERLAZIONATZEN DITUZTEN MEKANISMO BIOLOGIKOAK}

Obesitateak minbiziaren garapenean duen eragina azaltzen duten mekanismo molekularrak era ordenatuan azaldu ahal izateko, bost taldetan banatu ditugu (1.irudia):

- Intsulina/intsulinaren antzekoa den 1 hazkuntza-hormona (IGF-1).

- Sexu-esteroideak.

- Adipokinak.

- Hantura.

- Hormonen menpekoak ez diren mekanismoak. 
Saioa Gómez-Zorita, Jenifer Trepiana, Itziar Eseberri, María Puy Portillo

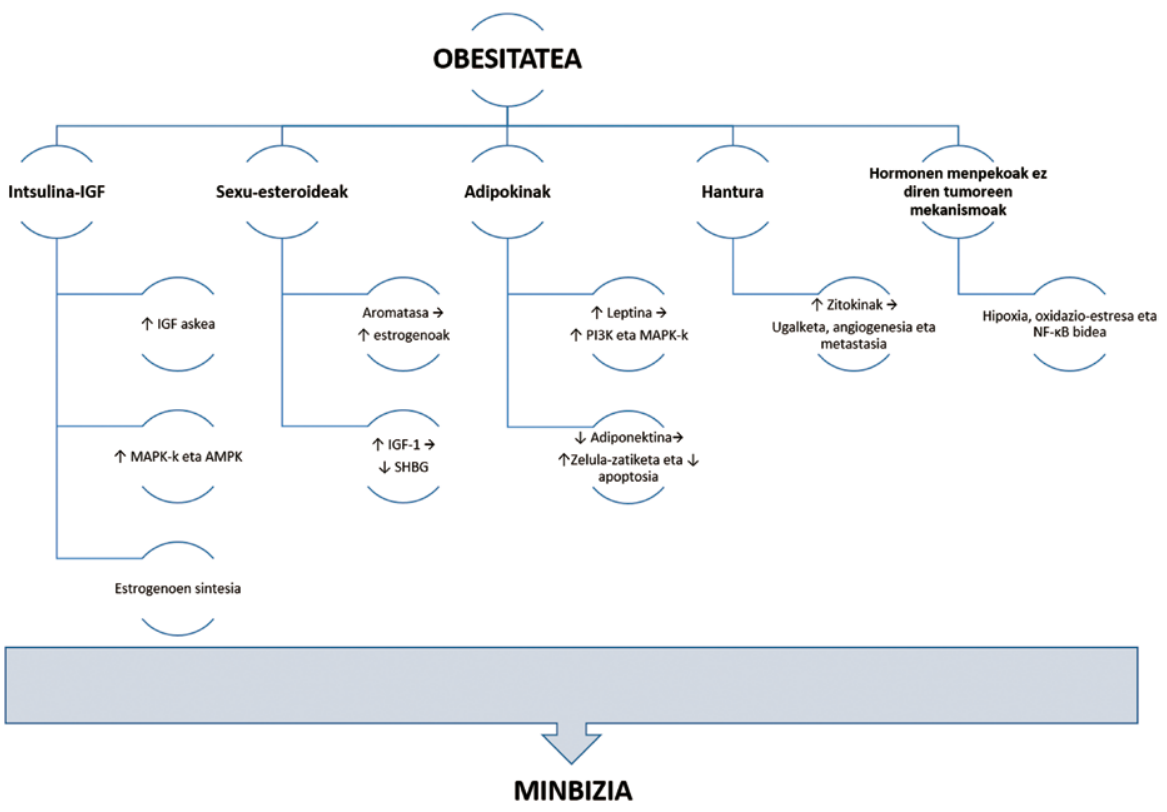

1. irudia. Minbiziaren eta obesitatearen arteko lotura eragiten duten mekanismo biologikoak. AMPK: AMP-k aktibaturiko proteina kinasa, IGF: intsulinaren antzekoa den hazkuntza-faktorea, MAPK: mitogenoak aktibaturiko proteina kinasa, NF- $x$ B: $x$ B faktore nuklearra, PI3K: fosfatidilinositol 3-kinasa, SHBG: sexu-hormonen globulina garraiatzailea.

\subsection{Intsulina/IGF}

Gaur egun ezaguna da intsulinak metabolismoaren erregulazioan eta organismoaren energia-metaketan duen rola. Gantz ase eta karbohidrato sinple (azukre) asko eta zuntz dietetiko gutxi ematen dizkiguten Mendebaldeko elikadura-patroiek, sedentarismoarekin bat eginez, gehiegizko pisua eta odoleko intsulina-maila altuegiak eragiten dituzte [15]. Obesitatea eta 2 motako diabetesa pairatzen dituzten pertsonek minbiziaren ondoriozko heriotza-tasa altuagoak dituzte, intsulinaren eta intsulinaren antzekoa den 1 hazkuntza faktorearen (IGF-1) mailen igoera bati egotzi izan zaiona. Aitzitik, bi hormonen maila baxuak mantentzen dituzten pertsona obesoen kasuan, minbiziaren intzidentzia baxuagoa da [16].

Hiperintsulinemia kronikoak IGF garraiatzen duen proteina murrizten $\mathrm{du}$, eta IGF askearen mailak handitu. Horren ondorioz, estrogenoen sintesiaren eragileak diren hanturaren aldeko zitokinen eta zenbait adipokinaren mailak handitu egiten dira, hainbat tumore motatan zelulen ugaltzea sustatzeagatik minbizia pairatzeko arriskua handituko dutenak [17]. Bes- 
talde, intsulina eta IGF-1 maila altuek zelulen hazkuntzan parte hartzen duten hartzaileen aktibitatea areagotzen dute, intsulinaren hartzailea (IR) eta IGF-1-aren hartzailea (IGF-1R) kasurako, zeintzuk tumore-zeluletan gain-espresatuak dauden. Hartzaile horien aktibazioak mitogenoak aktibaturiko proteina kinasaren (MAPK) bidea estimulatuko du, eta tumore askoren hazkuntza eragin, larruazaleko eta pankreako minbizietakoak bereziki $[18,19]$. Zehatzago, intsulinak MAPK-ren bitartez edo IGF-1-aren bioerabilgarritasunean eragiteagatik zelula-ugaltzea estimulatzen du. Horrek, sexu-hormonen mailen areagotzea dakar, estrogenoena bereziki. Ikerlan batzuetan behatu denez, bular, prostata, kolon eta birikako minbizia duten gaixoetan IGF-1-aren gainespresioa gertatzen da, eta hartzaile horren aktibazioak MAPK suspertzen du, azken batean zelula-ugaltzea eragingo duena [20, 21]. Bestalde, IR-en aktibazioak fosfatidilinositol 3 kinasa/Aktren (PI3K/Akt) bidea ere induzituko du, minbizi mota askotan aktibaturik aurkitzen dena [18]. Aurkeztutako datuek, obesitateari loturiko minbizi mota? askotan intsulinak rol garrantzitsua duela erakusten dute; \% 20ko murrizketa energetikoak, berriz, IGF-1-aren mailak eta, ondorioz, tumoreen hazkuntza txikiagotzen ditu [22]. Beste hitz batzuetan esanda, elikaduraren bidez eskuratutako energiaren murrizketak minbizia izateko arriskuaren intzidentzia murriztu dezake.

\subsection{Sexu esteroideak}

Ikerketa batzuen arabera, obesitatearen eta hainbat minbizi motaren arteko lotura sexu-hormona esteroideen areagotzean datza, besteak beste, estrogenoak, progesterona, androgenoak eta giltzurrungaineko esteroideak [17]. Zehazki, estrogeno eta progesteronak zelula-zatiketa bultzatu eta apoptosia (alegia, zelulen programaturiko heriotza) murrizten dute bular eta endometrioko tumore-zeluletan [13].

Gorputzeko gehiegizko gantzaren metaketa estrogenoak, progesterona eta androgenoak bezalako sexu-hormona esteroideen eraketarekin eta bioerabilgarritasun altuarekin erlazionatzen da [13]. GMI eta odoleko estrogeno-mailak zuzenki proportzionalak direla ikusi da, bai gizonezkoetan eta bai emakumezko menopausikoetan ere [23]. Lehen aipatu bezala, menopausia jasan duten emakumeek obulutegian estradiola eta progesterona sintetizatzen ez dutelako gertatzen da hori, estradiolaren iturri nagusia guruin adrenala eta gantz-ehuna izanik; azken horretan, aromatasa entzimak estrona estradiol bilakatzen du. Menopausia jasan duten emakumezkoetan gertatzen den estradiolaren sintesia «feedback edo atzeraelikadura» mekanismoaz erregulatuta ez dagoenez, obesitatea dutenen odoleko estradiol kontzentrazioa, normopisuan dauden emakume menopausikoetan baino bi bider altuagoa izatera irits daiteke [23]. Bestalde, aurretik azaldu den bezala, gainpisuan eta obesitatean intsulinaren eta IGF-1-aren maila-igoera nabarmena gertatzen da, testosteronaren eta estradiolaren garraiatzaile na- 
Saioa Gómez-Zorita, Jenifer Trepiana, Itziar Eseberri, María Puy Portillo

gusia den sexu-hormonen globulina garraiatzailearen (SHBG) sintesia inhibituko dutenak. Horren guztiaren ondorioz, sexu-esteroide askeen handitzea gertatuko denez, minbizia izateko arriskua handitu egingo da [24].

\subsection{Adipokinak}

Gantz-ehunak, erraien ingurukoak batik bat, adipokinak izeneko hazkuntza-faktoreak sintetizatu eta jariatzen ditu; horien artean, gehien ikertu eta ezagunenetarikoak dira adiponektina eta leptina. Adipokina horiek betetzen dituzten funtzio garrantzitsuenen artean, aipatzekoa da gantz-ehunaren eta hanturazko bideen artean egiten duten bitartekari-lana; leptinaren handitzeak eta adiponektinaren murrizketak, minbiziaren prozesuetan hainbat modutan eragin dezakete. Aipaturiko bi egoera horiek hantura-prozesuekin eta, zehatzago, 6-interleukina (IL-6) eta $\alpha$-tumore nekrosi faktorea (TNF- $\alpha$ ) bezalako hanturaren aldeko hainbat zitokinaren ekoizpenarekin erlazionaturik daude. Izan ere, bi zitokina horiek garrantzitsuak dira zelula-zatiketaren seinaleen aktibazioa, angiogenesia eta metastasia eragiten dituztelako.

Leptina energia-homeostasiaren erregulatzailea da, egoera fisiologikoetan janguraren inhibizioa eragiten baitu. Izan ere, obesitatea duten pertsonetan, gorputzeko gantz kantitatearekin zuzenki erlazionatzen da; hau da, zenbat eta gorputzeko gantz kantitate handiagoa, orduan eta altuagoa da odoleko leptina-maila. Hala eta guztiz ere, aipatzekoa da pertsona obesoek leptinarekiko erresistentzia garatu ohi dutela, eta seinalizazio-homeostasiaren kontrola aztoratu. B-linfoma zelulen kultiboekin eginiko ikerketetan ikusi denez, leptinak eginkizun garrantzitsua du minbiziaren garapenean, zeren eta minbizi-zelulen zatiketa handitzen, apoptosia murrizten, angiogenesia (odolbide berrien eraketa) eragiten eta metastasia (zelulen inbasioahalmena) faboratzen baitu. Izan ere, minbizi-zelulek leptinaren hartzailea gainespresatzen dute, eta PI3K/Akt eta MAPK bideen aktibazioa estimulatu [25-27].

Bestalde, adiponektina, gainerako ehunen intsulinarekiko sentikortasuna handitzen duen adipokina, maila baxuetan aurkitzen da obesitatea pairatzen duten pertsonen odolean, zeinak GMIrekin alderantzizko proportzionaltasuna jarraitzen duen [28]. Gaur egun, jakina da adiponektinak hainbat minbizi motaren intzidentzia, bularrekoa, biriketakoa edo tiroidearena esaterako, murriztu dezakeela, adiponektinaren hartzailea espresatzen duten minbizi-zeluletan proliferazioa gutxiagotuz apoptosiaren bidezko zelulen heriotza eragiten dutelako [29]. Gainera, adiponektinaren kanpotiko txertatzeak tumorearen angiogenesia eta hazkuntza gutxiagotzen duela ikusi da esperimentazio-animalietan [30]. Aipaturiko efektu horiek guztiak, adipokinak duen hanturaren eta diabetesaren kontrako izaerari esker gerta litezke. 
Leptinaz eta adiponektinaz gain, badaude obesitatearen eta minbiziaren arteko loturarekin erlazionaturiko beste adipokina batzuk, visfatina eta omentina-1, kasurako. Visfatinaren odol-mailak erraietako gantz-ehunaren kantitatearen zuzenki proportzionala da, eta bularreko eta kolon eta ondesteko minbiziekin estuki erlazionatu izan da [31]. Erraietako gantz-ehuneko adipozitoek omentina-1 ere jariatzen dute, hanturaren aurkako adipokina, zeina giltzurruneko kartzinoma duten pertsonetan nabarmenki murriztuta dagoela ikusi den [32]. Hala eta guztiz ere, bi adipokina horiek minbiziaren garapenean parte-hartze garrantzitsua izan badezakete ere, lotura hori ez dago oraindik leptinaren eta adiponektinaren artekoa bezain ondo finkatuta.

\subsection{Hantura}

Obesitateak hantura eta oxidazio-estres kronikoa dakar berekin, hanturaren aldeko zitokinen ekoizpena eta seinalizazio-bideen aktibazioa eragingo dutenak, azken batean obesitateari loturiko 2 motako diabetesa eta ateroesklerosia ekarriko dutenak [33].

Efektu kaltegarri hori, hein handi batean bada ere, gantz-ehunak egiten duen TNF- $\alpha$ edo IL- 6 bezalako zitokinen ekoizpenagatik gertatzen da, haien ekoizpenak hanturaren aldeko zitokina gehiago sintetizatuko dituzten makrofago eta linfozitoen sartzea eragingo baitu. Hantura kronikoak oxidazio-estresa handitzen duen aldetik, minbiziaren garapenean parte-hartze garrantzitsua duela esan daiteke, zelulen lipido, proteina eta material genetikoa aztoratuko duten erradikal askeen ekoizpenaren handitzea eragiten duelako.

Gantz-ehunean TNF- $\alpha$ eta IL-6 zitokinen ekoizpena areagotzen denean, gibel-zelulek fase akutuko hantura-proteinak askatuko ditu, $\mathrm{C}$ proteina erreaktiboa (CRP), kasurako [34]. Zientifikoki frogatutzat eman daiteke obesitatea duten pertsonek gehiegizko pisua ez dutenek baino hanturaren aldeko zitokina gehiago jariatzen dituztela [35], eta kontuan izanik hantura-prozesuak gehiegizko zelula-zatiketa eta migrazioa eragingo duela, kartzinogenesian (kolon eta ondesteko minbizian bereziki) esku-hartze handia duela esan daiteke [36].

Azkenik, garrantzitsua da azpimarratzea gantz-ehunaren hantura gordailu ezberdinetan aldi berean gertatzen dela, gantz-ehunaren gordailu baten hanturak besteengan eragiten duela iradokitzen duena. Halaber, gantz-ehunen mailan gertatzen den hanturaz gain, hanturaren aldeko markatzaile sistemikoen igoera ere antzeman daiteke [37]. Gauzak horrela, bai gantz-ehunaren hanturak eta bai hantura sistemikoak neoplasiaren aldeko ingurunean eragiten dute, aldi berean, eta metastasiaren arriskua handitzen da. 
Saioa Gómez-Zorita, Jenifer Trepiana, Itziar Eseberri, María Puy Portillo

\subsection{Hormonen menpekoak ez diren mekanismoak}

Aurreko azalpenetan oinarrituta, badirudi sexu-hormonak obesitatearen eta minbiziaren arteko loturan ezinbestekoak direla, eta hori hormonekiko sentikorrak diren tumoreetan soilik gertatzen dela. Aldiz, badira sexu-hormonen edo hormonen efektuari erantzuten ez diotenak ere. Tumore mota hauentzat beste mekanismo batzuk proposatu dira: besteak beste, obesitateari atxikituriko hipoxia, oxidazio-estresa, $\varkappa \mathrm{B}$ faktore nuklearraren $(\mathrm{NF}-\varkappa \mathrm{B})$ bidea eta faktore genetikoak, obesitatearen aurrejoera eragin dezaketenak eta, ondorioz, modu ez-zuzen batean, zenbait tumoreren intzidentzia handitu [24, 38, 39]. Obesitateari lotutako hipoxia gantz-ehunean oxigeno-maila baxua dagoenean gertatzen da, intsulinarekiko erresistentziarekin, adiponektinaren jariapenaren murrizketarekin eta leptinaren jarioaren handitzearekin erlazionatzen dena [24]. Bestetik, obesitatea duten pertsonetan ohikoa den oxidazio-estresa kartzinomen garapenarekin erlazionatu da, giltzurruneko minbizian batik bat [38]. Izan ere, oxidazio-estresaren eta minbiziaren arteko harreman hori, apoptosiaren gaineko erregulazioan eta DNAren kaltean oinarritzen da.

\section{OBESITATEAREN ETA METASTASIAREN ARTEKO LOTURA}

Metastasia minbiziak eragindako heriotza gehienen eragilea da. Aldi berean obesitatea eta minbizia pairatzen duten pazienteek metastasi-arrisku handiagoa dute, eta, ondorioz, biziraupen-ratio baxuagoa. Metastasi-prozesua osatzen duten faseak honako hauek dira: kartzinomaren garapena eta inbasio-ahalmenaren lorpena, zirkulazio-aparatuan barneratzeko ahalmena, inbasioa hasiko den kokalekuan finkatzea eta ehun sekundario horretan tumorearen egokitzapena eta hedapena [40] (2. irudia). Metastasia pizten duen prozesuari Trantsizio Epitelial-Mesenkimal (EMT) deritzo, non epitelio-zelula arrunt batek izandako aldaketa biokimiko batzuek zelula mesenkimalaren fenotipoa bere gain hartzea ahalbidetzen duten. Horrela, zelula horrek migraziorako, inbasiorako, apoptosirako erresistentzia eta zelula-kanpoko matrizearen proteinen ekoizpenerako ahalmen izugarria bereganatuko du, tumore-zeluletan bereizgarriak izaten diren ezaugarriak, alegia [41].

Egin diren ikerketa aurreklinikoetan ikusi ahal izan denez, obesitateak metastasia bultzatzen du melanoma eta birika-minbizi ereduetan [42]. Horrez gain, probatu da obesitateak ER+ diren bular-minbizi zelulen agresibitatea handitzen duela, zenbait adipokinaren jarioa handitzen eta $\mathrm{B}$ proteina kinasa/rapamizinaren ugaztun-itua (Akt/mTOR) zelula-bidearen aktibazioa eragiten duelako [43]. Zehatzago esanda, leptinak bular-minbiziaren tumore-zelulen EMT prozesuaren aktibazioa eragiten du Akt/GSK3 seinalizazio-bidearen bitartez [44]. Beraz, obesitateak metastasian parte hartzen du- 
ten EMT prozesuen aktibazioa eragin lezake, nahiz eta mekanismo horien inplikazioa baieztatzeko ikerketa gehiagoren beharra dagoen.

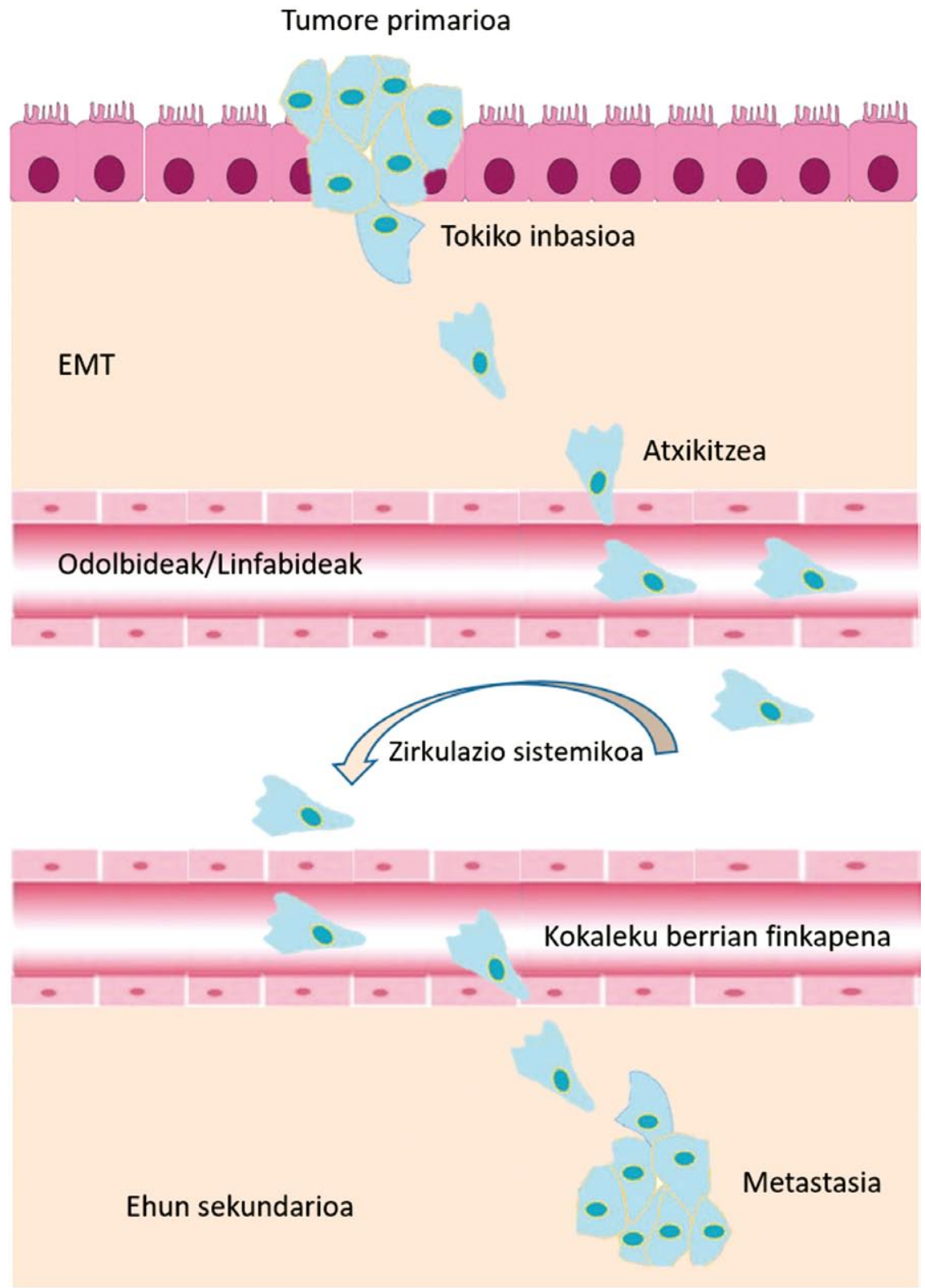

2. irudia. Metastasi-jauzian gertaturiko zelula-fenotipoaren aldaketak. Jiang eta haren kolaboratzaileetatik moldatua [40]. 
Saioa Gómez-Zorita, Jenifer Trepiana, Itziar Eseberri, María Puy Portillo

\section{MINBIZIA DUTEN PAZIENTEENTZAKO OBESITATEAREN KONTRAKO TRATAMENDU FARMAKOLOGIKOAK}

Obesitateak paziente onkologikoen hilkortasun-tasa altuarekin duen lotura ikusita, ezinbestekotzat jotzen da minbizia duten pazienteetan obesitatea eta sindrome metabolikoa tratatzeko estrategia multidiziplinarraren aplikazioa. Elikadura-patroi egokiaren jarraipena, ahal den neurrian jarduera fisikoaren sustapena eta tratamendu farmakologikoa biltzen dituena. Atal honetan, tratamendu farmakologikoa aztertuko da.

\subsection{Metformina}

Metformina 2 motako diabetesean erabilitako farmakoa da, kontrol gluzemikorako eta intsulinarekiko erresistentzia tratatzeko erabilgarria. Diabetesa obesitateari atxikitutako erikortasuna da, eta horrez gain, hilkortasun arriskuaren iragarlea zenbait minbizi motatan, besteak beste kolon, pankrea, bular, gibel eta prostatako minbizietan [45]. Farmako honen eginkizunak muskuluaren intsulinarekiko sentikortasuna handitzea, hesteko glukosaren absortzioa atzeratzea eta ehunen glukosaren kaptazioa bultzatzea dira. Bestalde, gibelaren glukosa-askapena murrizten du, glukogenolisi eta glukoneogenesia bidezidorren inhibizioa eragiteagatik. Hala ere, ez dago guztiz argi zer mekanismo den farmako hau erabilgarri egiten duena minbizia duten pazienteetan. Serina Treonina kinasa/AMP-k aktibaturiko proteina kinasa (SK11/AMPK) bidezidor metabolikoaren erregulatzailea izan litekeela ikusi da, AMPK-ren aktibazioak gantz-azidoen sintasa (FAS) entzimaren espresioa murrizten duelako, modu horretan lipidoen sintesia gutxituz. Gainera, AMPK-k glukosaren sintesia ere inhibitzen du mTOR bidearen bitartez. Bestetik, metforminak eragindako AMPK-ren aktibazioak hanturaren aldeko zitokinen sintesia eragotz dezake, angiogenesia murriztu, eta azken honen ondorioz, tumoreen hazkuntza inhibitu zenbait minbizi motatan [46]. Horrez gain, farmakoak obesitatea duten pertsonetan minbiziaren garapena bultzatzen duten intsulina eta IGF-1-en mailak murriztu ditzake. Horrekin guztiarekin, metforminak tumoreen progresioa intsulinarekiko sentikortasuna handituz egiten duela esan daiteke, batez ere tumore-zelulena areagotuta.

\subsection{Tiazolidinedionak}

Tiazolidinedionak (TZD) peroxisomen ugalketarako $\gamma$ hartzailearen (PPAR $\gamma$ ) agonistak diren farmakoen familia dira, duela zenbait urte 2 motako diabetesa tratatzeko erabilitakoak. Tumore-zelulen ziklo zelularra blokeatzeko gai den farmakoa da, minbiziaren kontrako terapietarako oso ikertua izan den fosfatasa eta tentsinaren homologoa den proteinaren (PTEN) bultzatzearen bitartez [47]. Izan ere, birika-minbizian TZD-ek zelulen hazkuntza eta apoptosia inhibi dezaketela egiaztatu izan da [48]. 


\subsection{Estatinak}

Hiperkolesterolemia tratatzeko gehien preskribaturiko farmakoak dira, kolesterolaren sintesiaren entzima mugatzailearen gain eraginda, odoleko kolesterol-mailak murriztu egiten dituztenak. Odolbideetan kolesterola maila altuan dagoenean, dentsitate baxuko lipoproteina (LDL) edo «kolesterol txar» moduan bereziki, bular edo prostata minbizietako tumore-zelulen ugalketaren alde egin dezake [49]. Minbiziaren diagnostikoa baino lehenago estatinak hartu izanak pazienteen hilkortasun-tasa murrizten du, minbizi mota edozein dela ere [50].

\section{ONDORIOAK}

Berrikuspen honen bidez, obesitatearen eta minbiziaren arteko lotura korapilatsua dela ondoriozta daiteke; horrekin batera, obesitatea osasun publikoko arazo larria dela ere agerian utzi dugu. Gaur egun ezarrita dago gorputzeko gehiegizko gantz-metaketa minbizi mota askoren arrisku-faktorea dela, esaterako, minbizi mota hauetan: kolon eta ondeste, endometrio, hestegorri, giltzurrun, pankrea eta, emakumezko menopausikoetan, bularreko minbizietan. Obario eta prostatako minbizien kasuan, asoziazio hori ere izan daitekeela uste da, baina ikerlan gehiagoren beharra dago parte hartzen duten mekanismoak ondo ulertu ahal izateko. Gainera, gorputz-gantzaren eta minbiziaren arteko loturan, bai hiperintsulinemiak eta bai adipokina eta sexu-hormonen maila desorekatuek parte hartzen dutela baieztatu da; izan ere, obesitateak eragindako hantura kronikoarekin erlazionatu da kolon eta ondesteko minbizia. Bukatzeko, aipatzekoa da obesitatearen eta minbiziaren arteko asoziazioa finkatzen duten mekanismoen azterketa ezinbestekoa dela etorkizunean minbiziaren diagnostiko goiztiarrerako baliagarriak izan litezkeen biomarkatzaileak aurkitzeko. Horrez gain, argi dago obesitatearen prebalentzia-tasak murrizteko beharra dagoela; horretarako estrategia ugari badago ere, ezinbestekoa da gizarteari bideratutako prebentzio-programa gehiagoren aplikazioa, batik bat haur eta gazteei zuzendurik.

\section{BIBLIOGRAFIA}

[1] Futreal, P.A.; Coin, L.; Marshall, M.; Down, T.; Hubbard, T.; Wooster, R.; Rahman, N.; Stratton, M.R. A census of human cancer genes. Nat. Rev. Cancer. 2004, 4, 177-183.

[2] Pan, M.H.; Ghai, G.; Ho, C.T. Food bioactives, apoptosis, and cancer. Mol. Nutr. Food Res. 2008, 52, 43-52.

[3] Bray, F.; Ferlay, J.; Soerjomataram, I.; Siegel, R.L.; Torre, L.A.; Jemal, A. Global cancer statistics 2018: GLOBOCAN estimates of incidence and mor- 
tality worldwide for 36 cancers in 185 countries. CA Cancer. J. Clin. 2018, 68, 394-424.

[4] Anand, P.; Kunnumakkara, A.B.; Sundaram, C.; Harikumar, K.B.; Tharakan, S.T.; Lai, O.S.; Sung, B.; Aggarwal, B.B. Cancer is a preventable disease that requires major lifestyle changes. Pharm. Res. 2008, 25, 2097-2116.

[5] Hales, C.M.; Fryar, C.D.; Carroll, M.D.; Freedman, D.S.; Ogden, C.L. Trends in Obesity and Severe Obesity Prevalence in US Youth and Adults by Sex and Age, 2007-2008 to 2015-2016. JAMA 2018, 319, 1723-1725.

[6] Marti, A.; Moreno-Aliaga, M.J.; Hebebrand, J.; Martinez, J.A. Genes, lifestyles and obesity. Int. J. Obes. Relat. Metab. Disord. 2004, 28 Suppl 3, S29-36.

[7] Steele, C.B.; Thomas, C.C.; Henley, S.J.; Massetti, G.M.; Galuska, D.A.; Agurs-Collins, T.; Puckett, M.; Richardson, L.C. Vital Signs: Trends in Incidence of Cancers Associated with Overweight and Obesity - United States, 2005-2014. MMWR Morb. Mortal. Wkly. Rep. 2017, 66, 1052-1058.

[8] Avgerinos, K.I.; Spyrou, N.; Mantzoros, C.S.; Dalamaga, M. Obesity and cancer risk: Emerging biological mechanisms and perspectives. Metabolism 2019, 92, 121-135.

[9] Ortiz-Mendoza, C.M.; Velasco-Navarro, C. Obesity, a main risk factor for endometrial cancer. Rev. Med. Inst. Mex. Seguro Soc. 2013, 51, 260-263.

[10] Bhardwaj, P.; Au, C.C.; Benito-Martin, A.; Ladumor, H.; Oshchepkova, S.; Moges, R.; Brown, K.A. Estrogens and breast cancer: Mechanisms involved in obesity-related development, growth and progression. J. Steroid Biochem. Mol.Biol. 2019, 189, 161-170.

[11] Wolin, K.Y.; Carson, K.; Colditz, G.A. Obesity and cancer. Oncologist 2010, 15, 556-565.

[12] Bianchini, F.; Kaaks, R.; Vainio, H. Overweight, obesity, and cancer risk. Lancet Oncol. 2002, 3, 565-574.

[13] Calle, E.E.; Rodriguez, C.; Walker-Thurmond, K.; Thun, M.J. Overweight, obesity, and mortality from cancer in a prospectively studied cohort of U.S. adults. N. Engl. J. Med. 2003, 348, 1625-1638.

[14] Basen-Engquist, K.; Chang, M. Obesity and cancer risk: recent review and evidence. Curr. Oncol. Rep. 2011, 13, 71-76.

[15] Pollak, M. The insulin and insulin-like growth factor receptor family in neoplasia: an update. Nat. Rev. Cancer. 2012, 12, 159-169.

[16] Gallagher, E.J.; LeRoith, D. Minireview: IGF, Insulin, and Cancer. Endocrinology 2011, 152, 2546-2551.

[17] Kaaks, R.; Lukanova, A.; Kurzer, M.S. Obesity, endogenous hormones, and endometrial cancer risk: a synthetic review. Cancer Epidemiol. Biomarkers Prev. 2002, 11, 1531-1543.

[18] Bol, D.K.; Kiguchi, K.; Gimenez-Conti, I.; Rupp, T.; DiGiovanni, J. Overexpression of insulin-like growth factor-1 induces hyperplasia, dermal abnormalities, and spontaneous tumor formation in transgenic mice. Oncogene 1997, 14, 1725-1734. 
[19] Lopez, T.; Hanahan, D. Elevated levels of IGF-1 receptor convey invasive and metastatic capability in a mouse model of pancreatic islet tumorigenesis. Cancer. Cell. 2002, 1, 339-353.

[20] Lima, M.M.; Velásquez, E.; Unshelm, G.; Christopher, T.; Francisco, R.; Lanza, P. Asociación de la insulina y el factor de crecimiento semejante a la insulina tipo 1 (IGF-1) en el cáncer de mama. Gaceta Médica de Caracas 2009, 117, 226-231.

[21] Herrera-Covarrubias, D.; Coria-Avila, G.A.; Fernández-Pomares, C.; Aranda-Abreu, G.E.; Manzo Denes, J.; Hernández, M.E. La obesidad como factor de riesgo en el desarrollo de cáncer. Revista Peruana de Medicina Experimental y Salud Publica 2015, 32, 766-776.

[22] Hursting, S.D.; Lavigne, J.A.; Berrigan, D.; Perkins, S.N.; Barrett, J.C. Calorie restriction, aging, and cancer prevention: mechanisms of action and applicability to humans. Annu. Rev. Med. 2003, 54, 131-152.

[23] Key, T.J.; Allen, N.E.; Verkasalo, P.K.; Banks, E. Energy balance and cancer: the role of sex hormones. Proc. Nutr. Soc. 2001, 60, 81-89.

[24] Roberts, D.L.; Dive, C.; Renehan, A.G. Biological mechanisms linking obesity and cancer risk: new perspectives. Annu. Rev. Med. 2010, 61, 301-316.

[25] Garofalo, C.; Koda, M.; Cascio, S.; Sulkowska, M.; Kanczuga-Koda, L.; Golaszewska, J.; Russo, A.; Sulkowski, S.; Surmacz, E. Increased expression of leptin and the leptin receptor as a marker of breast cancer progression: possible role of obesity-related stimuli. Clin. Cancer Res. 2006, 12, 1447-1453.

[26] Uddin, S.; Bu, R.; Ahmed, M.; Hussain, A.R.; Ajarim, D.; Al-Dayel, F.; Bavi, P.; Al-kuraya, K.S. Leptin receptor expression and its association with $\mathrm{PI} 3 \mathrm{~K} / \mathrm{AKT}$ signaling pathway in diffuse large B-cell lymphoma. Leuk. Lymphoma 2010, 51, 1305-1314.

[27] Dutta, D.; Ghosh, S.; Pandit, K.; Mukhopadhyay, P.; Chowdhury, S. Leptin and cancer: Pathogenesis and modulation. Indian. J. Endocrinol. Metab. 2012, 16, S596-600.

[28] Cruz-Mejia, S.; Duran Lopez, H.H.; Navarro Meza, M.; Xochihua Rosas, I.; De la Pena, S.; Arroyo Helguera, O.E. Body mass index is associated with interleukin-1, adiponectin, oxidative stress and ioduria levels in healthy adults. Nutr. Hosp. 2018, 35, 841-846.

[29] Di Zazzo, E.; Polito, R.; Bartollino, S.; Nigro, E.; Porcile, C.; Bianco, A.; Daniele, A.; Moncharmont, B. Adiponectin as Link Factor between Adipose Tissue and Cancer. Int. J. Mol. Sci. 2019, 20, 10.3390/ijms20040839.

[30] Brakenhielm, E.; Veitonmaki, N.; Cao, R.; Kihara, S.; Matsuzawa, Y.; Zhivotovsky, B.; Funahashi, T.; Cao, Y. Adiponectin-induced antiangiogenesis and antitumor activity involve caspase-mediated endothelial cell apoptosis. Proc. Natl. Acad. Sci. U. S. A. 2004, 101, 2476-2481.

[31] Berndt, J.; Kloting, N.; Kralisch, S.; Kovacs, P.; Fasshauer, M.; Schon, M.R.; Stumvoll, M.; Bluher, M. Plasma visfatin concentrations and fat depot-specific mRNA expression in humans. Diabetes 2005, 54, 29112916. 
[32] Shen, X.D.; Zhang, L.; Che, H.; Zhang, Y.Y.; Yang, C.; Zhou, J.; Liang, C.Z. Circulating levels of adipocytokine omentin-1 in patients with renal cell cancer. Cytokine 2016, 77, 50-55.

[33] Tahergorabi, Z.; Khazaei, M.; Moodi, M.; Chamani, E. From obesity to cancer: a review on proposed mechanisms. Cell Biochem. Funct. 2016, 34, 533545.

[34] Aronson, D.; Bartha, P.; Zinder, O.; Kerner, A.; Markiewicz, W.; Avizohar, O.; Brook, G.J.; Levy, Y. Obesity is the major determinant of elevated Creactive protein in subjects with the metabolic syndrome. Int. J. Obes. Relat. Metab. Disord. 2004, 28, 674-679.

[35] Fain, J.N. Release of interleukins and other inflammatory cytokines by human adipose tissue is enhanced in obesity and primarily due to the nonfat cells. Vitam. Horm. 2006, 74, 443-477.

[36] Tuomisto, A.E.; Makinen, M.J.; Vayrynen, J.P. Systemic inflammation in colorectal cancer: Underlying factors, effects, and prognostic significance. World J. Gastroenterol. 2019, 25, 4383-4404.

[37] Iyengar, N.M.; Gucalp, A.; Dannenberg, A.J.; Hudis, C.A. Obesity and Cancer Mechanisms: Tumor Microenvironment and Inflammation. J. Clin. Oncol. 2016, 34, 4270-4276.

[38] Gago-Dominguez, M.; Castelao, J.E. Lipid peroxidation and renal cell carcinoma: further supportive evidence and new mechanistic insights. Free Radic. Biol. Med. 2006, 40, 721-733.

[39] Xia, L.; Tan, S.; Zhou, Y.; Lin, J.; Wang, H.; Oyang, L.; Tian, Y.; Liu, L.; Su, M.; Wang, H.; Cao, D.; Liao, Q. Role of the NFkappaB-signaling pathway in cancer. Onco Targets Ther. 2018, 11, 2063-2073.

[40] Jiang, W.G.; Sanders, A.J.; Katoh, M.; Ungefroren, H.; Gieseler, F.; Prince, M.; Thompson, S.K.; Zollo, M.; Spano, D.; Dhawan, P.; Sliva, D.; Subbarayan, P.R.; Sarkar, M.; Honoki, K.; Fujii, H.; Georgakilas, A.G.; Amedei, A.; Niccolai, E.; Amin, A.; Ashraf, S.S.; Ye, L.; Helferich, W.G.; Yang, X.; Boosani, C.S.; Guha, G.; Ciriolo, M.R.; Aquilano, K.; Chen, S.; Azmi, A.S.; Keith, W.N.; Bilsland, A.; Bhakta, D.; Halicka, D.; Nowsheen, S.; Pantano, F.; Santini, D. Tissue invasion and metastasis: Molecular, biological and clinical perspectives. Semin. Cancer Biol. 2015, 35 Suppl, S244-S275.

[41] Kalluri, R.; Weinberg, R.A. The basics of epithelial-mesenchymal transition. J. Clin. Invest. 2009, 119, 1420-1428.

[42] Mori, A.; Sakurai, H.; Choo, M.K.; Obi, R.; Koizumi, K.; Yoshida, C.; Shimada, Y.; Saiki, I. Severe pulmonary metastasis in obese and diabetic mice. Int. J. Cancer 2006, 119, 2760-2767.

[43] Fuentes-Mattei, E.; Velazquez-Torres, G.; Phan, L.; Zhang, F.; Chou, P.C.; Shin, J.H.; Choi, H.H.; Chen, J.S.; Zhao, R.; Chen, J.; Gully, C.; Carlock, C.; Qi, Y.; Zhang, Y.; Wu, Y.; Esteva, F.J.; Luo, Y.; McKeehan, W.L.; Ensor, J.; Hortobagyi, G.N.; Pusztai, L.; Fraser Symmans, W.; Lee, M.H.; Yeung, S.C. Effects of obesity on transcriptomic changes and cancer hallmarks in 
estrogen receptor-positive breast cancer. J. Natl. Cancer Inst. 2014, 106, 10.1093/jnci/dju158. Print 2014 Jul.

[44] Yan, D.; Avtanski, D.; Saxena, N.K.; Sharma, D. Leptin-induced epithelialmesenchymal transition in breast cancer cells requires beta-catenin activation via Akt/GSK3- and MTA1/Wnt1 protein-dependent pathways. J. Biol. Chem. 2012, 287, 8598-8612.

[45] Coughlin, S.S.; Calle, E.E.; Teras, L.R.; Petrelli, J.; Thun, M.J. Diabetes mellitus as a predictor of cancer mortality in a large cohort of US adults. Am. J. Epidemiol. 2004, 159, 1160-1167.

[46] Morales, D.R.; Morris, A.D. Metformin in cancer treatment and prevention. Annu. Rev. Med. 2015, 66, 17-29.

[47] Teresi, R.E.; Shaiu, C.W.; Chen, C.S.; Chatterjee, V.K.; Waite, K.A.; Eng, C. Increased PTEN expression due to transcriptional activation of PPARgamma by Lovastatin and Rosiglitazone. Int. J. Cancer 2006, 118, 2390-2398.

[48] Satoh, T.; Toyoda, M.; Hoshino, H.; Monden, T.; Yamada, M.; Shimizu, H.; Miyamoto, K.; Mori, M. Activation of peroxisome proliferator-activated receptor-gamma stimulates the growth arrest and DNA-damage inducible 153 gene in non-small cell lung carcinoma cells. Oncogene 2002, 21, 2171-2180.

[49] Alikhani, N.; Ferguson, R.D.; Novosyadlyy, R.; Gallagher, E.J.; Scheinman, E.J.; Yakar, S.; LeRoith, D. Mammary tumor growth and pulmonary metastasis are enhanced in a hyperlipidemic mouse model. Oncogene 2013, 32, 961-967.

[50] Nielsen, S.F.; Nordestgaard, B.G.; Bojesen, S.E. Statin use and reduced cancer-related mortality. N. Engl. J. Med. 2012, 367, 1792-1802. 